\title{
HIV-1 induced autophagy modulation in Langerhans cells
}

\author{
Magdalena Czubala*, John Paul Mitchell, Fabien Blanchet, Vincent Piguet \\ From Frontiers of Retrovirology: Complex retroviruses, retroelements and their hosts \\ Cambridge, UK. 16-18 September 2013
}

\section{Background and aim}

Our research aims to decipher the mechanism and immune consequences imposed by HIV-mediated modulation of autophagy in challenged dendritic cell (DC) subsets, in particular Langerhans cells (LC). Autophagy is an ubiquitous cellular process involved in lysosomalmediated degradation of host components as well as invading pathogens. In previous reports, HIV-1 was shown to modulate the autophagy flux in various immune cell types, including $\mathrm{T}$ cells, macrophages and myeloid dendritic cells. However, very little is known about the potential autophagy-driven antiviral activity in LC.

\section{Methods}

LC used for this study were differentiated from either blood monocytes or the MUTZ-3 cell line model which phenotypically mimic LC morphology and immune features. LC were treated with wild type HIV-1, VSV-G pseudotyped HIV-1-derived lentivectors or recombinant HIV-1 envelopes. Levels of infection and cellular autophagy flux were analyzed by western blotting, FACS and confocal imaging.

\section{Results}

We observe that, as previously described for myeloid DC, autophagy flux is compromised in LC after exposure to HIV-1 envelope or infectious virus. Hence, activation of the autophagy negative regulator, mTOR, is detected, and could account for the autophagy flux inhibition. Although we could confirm the HIV-1 restriction activity of langerin and SAMHD-1 in LC, it appears that shutting down autophagy flux is an early cellular target for the virus thus strongly suggesting that it might be involved in HIV-1 clearance shortly upon viral entry.

\section{Conclusion}

In this study, we show that Langerin and SAMHD-1 are significantly restricting HIV-1 entry and replication in LC. However, an additional barrier to infection, such as autophagolysosome-mediated degradation of virus particles, may account for the low infection rate observed in LC. Our results suggest that autophagy flux is indeed dampened upon HIV-1 challenge which might favour virus progression. We further aim to examine the effect of autophagy modulation on virus infection of LC and consequent virus transmission to $\mathrm{CD} 4^{+} \mathrm{T}$ cells.

Published: 19 September 2013

doi:10.1186/1742-4690-10-S1-P23

Cite this article as: Czubala et al: HIV-1 induced autophagy modulation

in Langerhans cells. Retrovirology 2013 10(Suppl 1):P23.

Institute of Infection and Immunity, Cardiff University, Cardiff, UK

Submit your next manuscript to BioMed Central and take full advantage of:

- Convenient online submission

- Thorough peer review

- No space constraints or color figure charges

- Immediate publication on acceptance

- Inclusion in PubMed, CAS, Scopus and Google Scholar

- Research which is freely available for redistribution 